\title{
The Effect of Varying Protein Quality and Energy Intake on the Nitrogen Metabolism of Parenterally Fed Very Low Birthweight $(<1600$ g) Infants
}

\author{
B. DUFFY, T. GUNN, J. COLLINGE, AND P. PENCHARZ ${ }^{(40)}$
}

The Montreal Children's Hospital, Montreal, Quebec, and The Hospital for Sick Children, Toronto, Ontario, Canada

\section{Summary}

Net nitrogen retention (NNR) and rates of whole-body protein turnover $(Q)$, synthesis, and breakdown (B) were measured in 24 intravenously fed premature infants, birthweight $<1600 \mathrm{~g}$, at the end of the first week of life. Four regimes were used: Amigenglucose \pm Intralipid; Vamin-glucose \pm Intralipid. Mean protein intake was $2.7 \mathrm{~g} / \mathrm{kg} /$ day. Mean energy intakes were 68 to $98 \mathrm{kcal} /$ $\mathrm{kg} /$ day.

Vamin was a better protein source $(P<0.01)$, evidenced by a higher NNR; $72 \pm 2 \%$, cf. $56 \pm 4 \%$ at high-energy intakes. The high-energy intake also improved $(P<0.01)$ protein retention (NNR); 64 cf. $50 \%$. Infants receiving $2.9 \mathrm{~g}$ of Vamin (394 mg N)/ $\mathrm{kg} / \mathrm{day}$ and $85 \mathrm{kcal} / \mathrm{kg} /$ day of nonprotein intake retained nitrogen at intrauterine rates $(282 \pm 7 \mathrm{mg} / \mathrm{kg} / \mathrm{day})$.

Diet had no effect on $Q$, synthesis, or $B$. However, the protein source had a significant effect $(P<0.01)$ on the fraction of $\mathrm{N}$-flux coming from protein breakdown $(\mathrm{B} / \mathrm{Q}) ; \mathbf{7 1 . 1} \%$ for Vamin, $c f .77 .1 \%$ for Amigen. Similarly, energy intake had a significant effect $(P$ $<0.01$ ) on the fraction N-flux utilized for protein synthesis (S/Q); 91.3\% high energy cf. $87.0 \%$ low energy. These results suggest that an increased energy intake improved $\mathrm{N}$-retention by enhancing amino acid reutilization for protein synthesis, whereas a higher quality protein improved $\mathrm{N}$-retention by limiting protein breakdown.

\section{Speculation}

Improved protein quality may inhibit breakdown by ensuring that a more complete and balanced mix of amino acids are available for protein synthesis. Where the protein quality is less ideal, endogenous proteins are catabolized to provide the necessary amounts and balance of amino acids at the ribosomal level for protein synthesis.

Small premature human infants (birthweight, $<1500 \mathrm{~g}$ ) at birth have very limited protein and energy reserves $(16,32)$. Their approximate duration of survival in starvation is about 7 days and with semistarvation, about 21 days (16). Clearly, there is an urgent need to establish an adequate nutrient intake, particularly of protein energy. Many of these infants have respiratory distress (15) and gastrointestinal immaturity $(6,31)$ which make enteral feeding difficult, if not impossible, during the first week of life. As a result, it has become accepted clinical practice to use supplemental or total parenteral nutrition (TPN) in the nutritional support of these infants during the first few weeks of life $(6,15)$. The addition of a soybean oil emulsion (Intralipid) to TPN regimes of amino acids and glucose permits adequate energy to be given by peripheral vein $(6,15)$. However, during the first week of life, there are concerns regarding the use of Intralipid because its use could potentially result in an increase in plasma free fatty acids $(3,4,11)$. These fatty acids in turn could displace unconjugated bilirubin from its binding sites on plasma albumin and so, potentially result in kernicterus $(3,4,11)$.

The work of Fomon and Ziegler (10), Gaull et al. (13), and Raiha et al. (27) has underlined the importance of taking into account protein quality as well as quantity in considering protein requirement in orally fed preterm infants. We now report a study of varying energy intake and protein quality on the nitrogen metabolism of small $(<1600 \mathrm{~g})$ parenterally fed premature infants during the first week of life.

\section{MATERIALS AND METHODS}

\section{SUBJECTS AND TPN REGIMES}

Twenty-four preterm infants with birth weights less than 1600 $\mathrm{g}$ (all but three were $<1500 \mathrm{~g}$; range, 960 to $1590 \mathrm{~g}$ ) were studied in the Neonatal Intensive Care Unit of the Montreal Children's Hospital. They were divided into four equal groups, each group receiving a different TPN regime. The clinical characteristics of the four groups are shown in Table 1. Two different sources of amino acids were used at two different energy levels, making up the four TPN regimes used. The amino acid sources were a casein hydrolysate (Amigen; Baxter Laboratories, Chicago, IL) and a crystalline amino acid mixture patterned on egg albumin (Vamin; Vitrum Co., A.B. Stockholm, Sweden) (34). The amino acid solutions had dextrose, mineral, and vitamin additions similar to those previously reported (15). The amino acid glucose solutions were either infused alone or in combination with $10 \%$ Intralipid (Vitrum Co.) (34) making up the four different TPN regimes. Similar daily fluid, amino acid, and mineral intakes per $\mathrm{kg}$ were given in all four groups.

\section{PROCEDURES}

The studies were approved by the Human Experimentation Committee of the Montreal Children's Hospital, and informed written consent was obtained from the parents. The infants were randomly allocated to one of the four TPN regimes, and intravenous feeding was started within the first $24 \mathrm{hr}$ of life. Infusion rates were increased as tolerated, and $72-\mathrm{hr}, \mathrm{N}$-balance, wholebody protein turnover, and skeletal muscle breakdown studies were performed during the fifth, sixth, and seventh days of life. Our balance techniques have been previously described (24). The infants were carefully monitored clinically and biochemically as previously reported (15). They were weighed daily, when clinically feasible, on a scale accurate to $\pm 5 \mathrm{~g}$. Weight gain during the study period was calculated on a 4-day period including the period of the N-balance.

All studies were performed with the neonate in a standard 
Table 1. Clinical characteristics

\begin{tabular}{lccc}
\hline & \multicolumn{3}{c}{ Characteristic } \\
\cline { 2 - 4 } & $\begin{array}{c}\text { Birth wt } \\
\text { Diet group }\end{array}$ & $\begin{array}{c}\text { Gestational age } \\
(\mathrm{wk})\end{array}$ & $\begin{array}{c}\text { Wt gain } \\
(\mathrm{g} / \text { day })\end{array}$ \\
\hline $\begin{array}{l}\text { Amigen } \\
\text { High energy }\end{array}$ & $1197 \pm 80^{2}$ & $29.7 \pm 0.4$ & $9 \pm 3^{\mathrm{a}}$ \\
Low energy & $1165 \pm 79$ & $28.8 \pm 0.8$ & $16 \pm 10^{\mathrm{a}}$ \\
& & & \\
Vamin & & & $62 \pm 23^{\mathrm{b}}$ \\
High energy & $1394 \pm 84$ & $30.0 \pm 1.0$ & $35 \pm 14^{\mathrm{b}}$ \\
Low energy & $1289 \pm 80$ & $29.8 \pm 0.8$ & \\
\hline
\end{tabular}

${ }^{1}$ There was a significant difference in weight gain (during the study period) $(P<0.01)$ between the protein groups $(\mathrm{a}<\mathrm{b})$ by two-way analysis of variance.

${ }^{2}$ Mean \pm S.E

servo-controlled incubator. Most infants required continuous airway-distending pressure (either positive or negative), and many required respirator assistance (either positive or negative) during the first week of life.

\section{TOTAL-BODY N-TURNOVER STUDIES}

To study the dynamic aspects of whole-body nitrogen metabolism, we used the approach described by Picou and Taylor-Roberts (25) and modified by Steffee et al. (30). ${ }^{15} \mathrm{~N}-$ Glycine, approximately 95 atoms percent enriched (Merck, Sharp and Dohme Ltd. Dorval, Quebec, Canada), was dissolved in distilled water, and the resulting solution was sterilized by passage through a $0.22 \mu$ Millipore Filter (Millipore Corp., Bedford, MA). The sterilized ${ }^{15} \mathrm{~N}$-glycine solution was then put into single-dose vials. Each batch of vials was monitored for sterility, and random vials were pyrogen tested. The ${ }^{15} \mathrm{~N}$-glycine was given intravenously every 3 $\mathrm{hr}$ during the 72-hr balance-turnover study in a dose of approximately $0.6 \mathrm{mg}{ }^{15} \mathrm{~N}$ per kg per day. Urine was collected immediately before each ${ }^{15} \mathrm{~N}$-glycine dose and at the end of the study for ${ }^{15} \mathrm{~N}$ urea analysis. The enrichment of the ${ }^{15} \mathrm{~N}$-glycine was verified by mass spectroscopy.

\section{ANALYSES}

Amino acid solutions, urine, nasogastric aspirates, and feces were analyzed for total nitrogen (20). Urinary 3-methyl histidine and plasma amino acids were measured using a Beckman $120 \mathrm{C}$ amino acid analyser (Beckman Instruments Inc., Palo Alto, CA). Urinary urea- $\mathrm{N}$ was isolated as previously described $(24,30)$, and its ${ }^{15} \mathrm{~N}$-content was determined with the aid of a dual inlet, double collector isotope-ratio mass spectrometer (Vacuum Generators, Micromass 602D, Winsford, Cheshire, England) (23).

\section{DATA ANALYSIS}

The ${ }^{15} \mathrm{~N}$ - enrichment of urinary urea was calculated as previously described (24). The plateau value of ${ }^{15} \mathrm{~N}$-enrichment of urea was determined by visual inspection as previously described $(24$, 30 ). A representative time course of urinary ${ }^{15} \mathrm{~N}$ urea enrichment is shown in Figure 1. Statistical evaluations were performed with a two-way analysis of variance (amino acid source and energy intake) (8).

\section{RESULTS}

\section{CLINICAL COURSE}

Most infants required respirator assistance in the form of continuous airway-distending pressure either negative ( 11 infants) or positive (eight infants). Nine of these nineteen infants also required ventilatory assistance at some time during their hospital stay, most during the first week of life. Apnoeic spells were common and were treated with caffeine administration. There were no significant differences between the groups in respirator or caffeine use. Phototherapy was begun as soon as an increase in serum bilirubin occurred. The mean maximum bilirubin levels were not significantly different, although the high-energy (Intralipid receiving) group had lower levels of both total and unconjugated bilirubin; the values were: high energy, $9.1 \pm 1.0 \mathrm{mg} / \mathrm{dl}$ total and $7.7 \pm 1.0 \mathrm{mg} / \mathrm{dl}$ unconjugated; low energy, $10.8 \pm 1.1$ and $9.0 \pm 1.0 \mathrm{mg} / \mathrm{dl}$, respectively.

The purpose of this study was to look at the nitrogen metabolism of the seriously ill, small preterm during the first week of life. Long-term follow-up studies of the children are being carried out in the Neonatal Follow-up Clinic. It is important to note that none of these infants died during the neonatal period.

\section{INTAKES, WEIGHT GAIN, AND NITROGEN RETENTION}

Protein and energy intakes are shown in Table 2. All four TPN groups received approximately the same amino acid intake $(2.67$ $\pm 0.3 \mathrm{~g} / \mathrm{kg} /$ day); the high-energy groups (those receiving Intralipid) received approximately $93 \mathrm{kcal} / \mathrm{kg} / \mathrm{day}$, and the low-energy group received $68 \mathrm{kcal} / \mathrm{kg} /$ day. Nitrogen intakes in the Vamin groups were higher (Table 3$)(P<0.01)$ because nitrogen analysis revealed that Vamin has a higher nitrogen content per gram of amino acid than Amigen. There were significant differences in $\mathrm{N}-$ balance and apparent nitrogen retention attributable to energy intake $(P<0.01)$ and type of amino acid mixture used $(P<$ $0.001)$. The infants receiving Vamin gained significantly $(P<$ $0.01)$ more weight than did those receiving Amigen at both levels of energy intake. The variation in the weight gain data was high

$$
\text { URINARY }{ }^{15} \mathrm{~N} \text { UREA ENRICHMENT }
$$

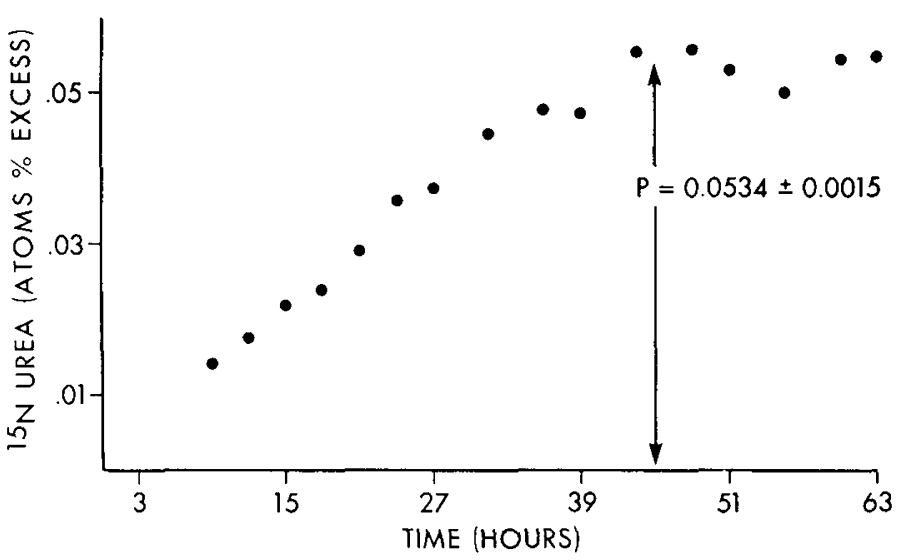

Fig. 1. The time course of urinary ${ }^{15} \mathrm{~N}$ urea in a representative baby.

Table 2. Daily protein and energy intakes

\begin{tabular}{|c|c|c|c|}
\hline \multirow[b]{2}{*}{ Diet group } & \multicolumn{3}{|c|}{ Intake } \\
\hline & $\begin{array}{c}\text { Protein } \\
\text { (g/kg/day) }\end{array}$ & $\begin{array}{l}\text { Total energy } \\
\text { (kcal/kg/day) }\end{array}$ & $\begin{array}{c}\text { Nonprotein } \\
\text { energy } \\
\text { (kcal/g N } \\
\text { intake) }\end{array}$ \\
\hline \multicolumn{4}{|l|}{ Amigen } \\
\hline High energy & $2.7 \pm 0.2^{2}$ & $90 \pm 4^{a}$ & $241 \pm 15^{\mathrm{a}}$ \\
\hline Low energy & $2.5 \pm 0.1$ & $66 \pm 3^{b}$ & $181 \pm 17^{b}$ \\
\hline \multicolumn{4}{|l|}{ Vamin } \\
\hline High energy & $2.9 \pm 0.1$ & $96 \pm 4^{a}$ & $213 \pm 7^{\mathrm{a}}$ \\
\hline Low energy & $2.6 \pm 0.1$ & $70 \pm 1^{b}$ & $171 \pm 11^{b}$ \\
\hline
\end{tabular}

'There are significant differences in total and nonprotein energy intake between the high- and low-energy diet groups $(\mathrm{a}>\mathrm{b})(P<0.001)$.

${ }^{2}$ Mean \pm S.E. 
(Table 1), and thus, the weight gain results must be interpreted with caution.

\section{TOTAL-BODY PROTEIN TURNOVER AND SKELETAL MUSCLE PROTEIN BREAKDOWN}

Rates of whole-body nitrogen flux (Q), protein synthesis (S), and breakdown (B) are shown in Table 4. All three rates were approximately $20 \%$ higher in the infants receiving the high-energy intake, but the differences were not statistically significant, in part because of the variation in the data. The differences in protein synthetic rates came close to statistical significance $(P<0.1$, but $>0.05$ by two-way analysis of variance). Significant differences were, however, seen in the fraction of N-flux (Q) that came from protein breakdown $(\mathrm{B} / \mathrm{Q} \times 100)(P<0.01)$ and that which was used for protein synthesis $(\mathrm{S} / \mathrm{Q} \times 100)(P<0.01)($ Table 5$)$. The

Table 3. Nitrogen intake, balance, and apparent retention

\begin{tabular}{|c|c|c|c|}
\hline \multirow[b]{2}{*}{ Diet group } & \multicolumn{3}{|c|}{ Nitrogen } \\
\hline & $\begin{array}{c}\text { Intake }^{1} \\
\text { (mg N/kg/ } \\
\text { day) }\end{array}$ & $\begin{array}{c}\text { Balance }^{2} \\
\text { (mg N/kg/day) }\end{array}$ & $\begin{array}{c}\text { Retention }^{2} \\
(\%)\end{array}$ \\
\hline \multicolumn{4}{|l|}{ Amigen } \\
\hline High energy & $333 \pm 19^{a, 3}$ & $187 \pm 20^{c, e}$ & $56 \pm 4^{\mathrm{c}, \mathrm{e}}$ \\
\hline Low energy & $314 \pm 13^{\mathrm{a}}$ & $125 \pm 20^{\mathrm{d}, \mathrm{e}}$ & $39 \pm 6^{\mathrm{d}, \mathrm{e}}$ \\
\hline \multicolumn{4}{|l|}{ Vamin } \\
\hline High energy & $394 \pm 13^{b}$ & $284 \pm 7^{c, f}$ & $72 \pm 2^{\mathrm{c}, \mathrm{f}}$ \\
\hline Low energy & $351 \pm 14^{b}$ & $214 \pm 20^{\mathrm{d}, \mathrm{f}}$ & $61 \pm 4^{\mathrm{d}, \mathrm{f}}$ \\
\hline
\end{tabular}

${ }^{1}$ There are significant differences in $\mathrm{N}$-intake between the two protein groups $\mathbf{a}<\mathrm{b}(P<0.01)$.

${ }^{2}$ Both energy intake and protein quality affected nitrogen balance and apparent nitrogen retention: $\mathrm{c}>\mathrm{d}(P<0.01)$; $\mathrm{e}<\mathrm{f}(P<0.001)$, respectively.

${ }^{3}$ Mean \pm S.E.

Table 4. Rates of total-body protein turnover

\begin{tabular}{|c|c|c|c|}
\hline \multirow[b]{2}{*}{ Diet group } & \multicolumn{3}{|c|}{ Total body } \\
\hline & $\begin{array}{c}\mathrm{Q} \\
(\mathrm{mg} \mathrm{N} / \mathrm{kg} / \mathrm{hr})\end{array}$ & $\begin{array}{c}\mathrm{S} \\
(\mathrm{g} / \mathrm{kg} / \text { day })\end{array}$ & $\begin{array}{c}\mathrm{B} \\
(\mathrm{g} / \mathrm{kg} / \text { day })\end{array}$ \\
\hline \multicolumn{4}{|l|}{ Amigen } \\
\hline High energy & $64.3 \pm 4.8^{2}$ & $8.75 \pm 0.79$ & $7.56 \pm 0.77$ \\
\hline Low energy & $57.9 \pm 5.7$ & $7.53 \pm 1.02$ & $6.72 \pm 0.93$ \\
\hline \multicolumn{4}{|l|}{ Vamin } \\
\hline High energy & $63.7 \pm 8.4$ & $8.89 \pm 1.38$ & $7.10 \pm 1.35$ \\
\hline Low energy & $50.0 \pm 3.0$ & $6.79 \pm 1.07$ & $5.31 \pm 0.45$ \\
\hline
\end{tabular}

Table 5. Economy of nitrogen utilization

\begin{tabular}{lll}
\hline \multicolumn{1}{c}{ Diet group } & $\mathrm{S} / \mathrm{Q} \times 100^{1}$ & $\mathrm{~B} / \mathrm{Q} \times 100^{2}$ \\
\hline Amigen & & \\
High energy & $90.4 \pm 1.3^{\mathrm{a}, 3}$ & $77.9 \pm 1.9^{\mathrm{c}}$ \\
Low energy & $85.6 \pm 2.2^{\mathrm{b}}$ & $76.3 \pm 2.2^{\mathrm{c}}$ \\
& & \\
Vamin & $92.3 \pm 0.9^{\mathrm{a}}$ & $72.0 \pm 2.3^{\mathrm{d}}$ \\
High energy & $88.5 \pm 1.3^{\mathrm{b}}$ & $70.3 \pm 1.8^{\mathrm{d}}$ \\
\hline
\end{tabular}

${ }^{1}$ There were significant differences between the two energy groups $(P$ $<0.01)$ in S/Q $\times 100$ by two-way analysis of variance $(\mathrm{a}>\mathrm{b})$.

${ }^{2}$ There were significant differences between the two protein groups ( $P$ $<0.01)$ in $\mathrm{B} / \mathrm{Q} \times 100$ by two-way analysis of variance $(\mathrm{c}>\mathrm{d})$.

${ }^{3}$ Mean \pm S.E. differences in $B / Q$ were attributable to the type of amino acid intake, and those in S/Q were attributable to the level of energy intake. Rates of skeletal muscle protein breakdown were calculated from urinary 3-methyl histidine excretion on the assumption that the 3-methyl histidine content of skeletal muscle is 1.7 umoles/g protein (33). The mean rate of skeletal muscle protein breakdown was $0.6 \mathrm{~g} / \mathrm{kg} / \mathrm{day}$. Although there was a tendency for lower rates of muscle protein breakdown in the Vamin groups compared with the Amigen groups, the differences were not statistically different (Table 6).

\section{DISCUSSION}

\section{CLINICAL COURSE}

Brans (5) critically reviewed the use of TPN in the very low birth weight infant up to 1977 and concluded that the benefits were slight, and the complications using central lines were serious. More recently, Gunn et al. (15) have reported a $71 \%$ survival rate in less than $1500 \mathrm{~g}$ neonates with respiratory distress syndrome who received TPN as compared with a $37 \%$ survival in the control group who received only $10 \%$ glucose and electrolytes. Most (79\%) of our infants had respiratory distress. Peripheral veins were used to administer TPN without any serious complications being encountered. Furthermore, all infants survived the neonatal period. Our data then would support that of Gunn et al. (15) and Cashore et al. (6) that TPN administered by peripheral veins offers real benefits with mininal complications in the very low birth weight neonates $(<1500 \mathrm{~g})$, provided careful monitoring is used.

\section{NITROGEN UTILIZATION}

The improved nitrogen utilization with the higher energy intake is not surprising and is in keeping with similar studies in intravenously (17) or orally (12) fed adults. The nitrogen retentions in the Vamin high-energy group approximate those seen for 1000 to $1500 \mathrm{~g}$ infants in utero (32). This suggests that the levels of Vamin $(2.9 \pm 0.2 \mathrm{~g} / \mathrm{kg} /$ day $)$ and total energy $(96 \pm 9 \mathrm{kcal} / \mathrm{kg} /$ day $)$ were adequate to meet the protein energy needs of $<1500 \mathrm{~g}$ neonates, at least during the first week of life. Furthermore, because the efficiency of nitrogen utilization by the Vamin-fed group was significantly $(P<0.01)$ better than that of the Amigen group, it may be inferred that the Vamin is a higher quality protein (9) than is Amigen. The data suggest that Vamin is a more suitable amino acid source for TPN in premature human infants than is Amigen. The apparent nitrogen retention of Vamin at the highenergy level $(72 \pm 4 \%)$ is comparable to the retention of absorbed nitrogen (biological value, $72.6 \%$ ) seen in a study (23) of orally fed infants. It is of interest to note that the apparent nitrogen retention of Amigen on the low-energy intake $(39 \pm 16 \%)$ is similar to the value obtained by Anderson et al. (1) in a similar earlier study (37\% of infused nitrogen). Anderson's study compared the utilization of another crystalline amino acid mixture

Table 6. Rates of skeletal muscle protein breakdown and its relationship to total body protein breakdown ${ }^{1}$

\begin{tabular}{|c|c|c|c|}
\hline Diet group & $\begin{array}{c}\text { Skeletal muscle } \\
\text { protein breakdown } \\
(\mathrm{g} / \mathrm{kg} / \text { day })\end{array}$ & $\begin{array}{c}\text { Total body protein } \\
\text { breakdown (B) } \\
(\mathrm{g} / \mathrm{kg} / \text { day })\end{array}$ & $\frac{\mathrm{SM}^{2}}{\mathrm{~B}} \times 100$ \\
\hline \multicolumn{4}{|l|}{ Amigen } \\
\hline High energy & $0.72 \pm 0.10^{3}$ & $7.56 \pm 0.77$ & $10.2 \pm 1.8$ \\
\hline Low energy & $0.79 \pm 0.12$ & $6.72 \pm 0.93$ & $12.6 \pm 2.4$ \\
\hline \multicolumn{4}{|l|}{ Vamin } \\
\hline High energy & $0.63 \pm 0.09$ & $7.10 \pm 1.35$ & $9.2 \pm 1.2$ \\
\hline Low energy & $0.53 \pm 0.15$ & $5.31 \pm 0.45$ & $10.3 \pm 3.2$ \\
\hline
\end{tabular}

${ }^{1}$ There were no statistically significant differences between any of the diet groups.

${ }^{2} \mathrm{SM}$, skeletal muscle protein breakdown.

${ }^{3}$ Mean \pm S.E. 
(Travasol; Baxtor Laboratories, Chicago, IL) with Amigen and comcluded that Amigen was the better of the two (1). Studies in adults had previously shown that the apparent nitrogen retention of crystalline amino acid mixtures were superior to those of the protein hydrolysates $(2,19)$. On purely theoretical grounds, a crystalline amino acid mixture based on egg albumen, such as Vamin, should be well utilized (9), as has been confirmed in these studies. Perhaps a more ideal "reference pattern" upon which to base a TPN amino acid mixture might be human milk. Trials using such a mixture have been reported (18), but do not include any measurement of nitrogen balance. The amino acid metabolism of small premature infants is immature (27), and concern has, therefore, been raised regarding the effect of any feeding regime, enteral or parenteral, on plasma amino acid patterns. Amino acid levels were measured in some of these infants; however, for technical and practical reasons, the data for each of the diet groups are incomplete. The data we did obtain are comparable to Anderson et al. (1) for Amigen and Dale et al. (7) for Vamin. In view of the significantly better utilization of Vamin, it is pertinent to consider the amino acid patterns of the Vamin-fed infants. Compared with the plasma amino acid levels seen in prematures fed human milk (26), significant elevations were seen only in threonine $(21.0 \pm 5.4 \mu \mathrm{moles} / \mathrm{dl})(n=5)$, and phenylalanine $(12.0 \pm 1.6$ $\mu$ moles/dl) $(n=5)$. The level of phenylalanine, although elevated above the comparison standard, is still within the normal range (28). The elevation of Threonine is modest and is comparable to levels reported for formula-fed infants (28).

\section{TOTAL-BODY PROTEIN TURNOVER AND SKELETAL MUSCLE PROTEIN BREAKDOWN}

A striking finding of this study is that the rates of $Q, S$, and $B$ are approximately one-half those seen in our orally fed infants of similar birth weight $(23,24)$. A similar phenomenon has been described in adults (29) where a $33 \%$ reduction in protein synthesis was noted on intravenous feeding compared with oral feeding. It was suggested that the differences were due to reduced synthesis of intestinal proteins during intravenous feeding (29). We (22) have offered an alternative explanation that during intestinal feeding virtually all amino acids from the diet pass up the portal vein and through the liver. This may result in increased formation of unlabeled urea from exogenous sources, which would tend to dilute out the ${ }^{15} \mathrm{~N}$ urea formed from the administered nitrogen-15 label. The resulting lower plateau of urinary ${ }^{15} \mathrm{~N}$ urea would raise the estimate of $\mathrm{N}$-flux, protein synthesis, and breakdown because $\mathrm{N}$-flux is inversely proportional to plateau. The route of isotope administration, either oral or intravenous, has been shown to make no difference to the rates of protein turnover measured in 1year-old infants (25) and adults (30). No such data are available in neonates. More recently, in meal fed 6- to 10-year old children, we have seen a diurnal variation in ${ }^{15} \mathrm{~N}$ urea excretion (21). During the day in which the children ate, their urinary urea- $\mathrm{N}$ excretion increased and ${ }^{15} \mathrm{~N}$ urea concentration fell; the reverse occurred at night. The fluctuation accounted for approximately 25 to $30 \%$ changes in the estimates of $\mathrm{N}$-flux. It is likely that the much larger differences seen in these premature intravenously fed infants are due in part to both postulated mechanisms, namely gut protein synthesis and isotope dilution. A key assumption of the protein turnover model used for these studies is that exogenous (dietary) and endoenous nitrogen are handled in the same fashion (25); evidently they may not be. Clearly, this problem requires further examination using different isotopic techniques; for example, [1${ }^{13}$ C]leucine (14).

Although the absolute rates of protein turnover may be in question, the relative rates of the four diet groups and the insight they give into the regulation of the neonate's protein metabolism are still valid (14). Previous authors (29) have described a reduction in total body protein synthesis with the removal of all nonprotein energy intake in intravenously fed adults. The present study, however, is the first demonstration of an effect of energy intake on the utilization of amino nitrogen flux for protein syn- thesis over a narrower range of energy intake. We are not aware of any previous studies of the effect of protein quality on wholebody nitrogen turnover. It is of interest, then, to note that the high-quality protein (Vamin) resulted in a reduced contribution of $\mathrm{N}$-flux coming from protein breakdown. It can tentatively be concluded that improved protein quality enhanced net nitrogen retention by slowing protein degradation. The cellular mechanisms for this kind of adaptation are not clear. There were no detectable effects of diet on skeletal muscle protein breakdown. Thus, it appears that the enhancement of nitrogen retention is due principally to changes in the protein metabolism of visceral organs and/or the brain.

\section{REFERENCES AND NOTES}

1. Anderson, G. H., Bryan, H., Jeejeebhoy, K. N., and Corey, P.: Dose-response relationships between amino acid intake and blood levels in newborn infants. Am. J. Clin. Nutr., 30: 1110 (1977).

2. Anderson, G. H., Patel, D. G., and Jeejeebhoy, K. N.: Design and evaluation by nitrogen balance and blood aminograms of an amino acid mixture for total parenteral nutrition of adults with gastrointestinal disease. J. Clin. Invest., 53: 904 (1974).

3. Andrew, G., Chan, G., and Schiff, D.: Lipid metabolism in the neonate. I. The effects of Intralipid infusion on plasma triglyceride and free fatty acid concentrations in the neonate. J. Pediatr., 88: 273 (1976).

4. Andrew, G., Chan, G., and Schiff, D.: Lipid metabolism in the neonate. II. The effect of Intralipid on bilirubin binding in vitro and in vivo. J. Pediatr, 88: 279 (1976).

5. Brans, Y. W.: Parenteral nutrition of the very low birthweight neonate. A critical view. Clin. Perinatol, 4: 367 (1977).

6. Cashore, W. J., Sedaghatian, M. R., and Usher, R. H.: Nutritional supplements with intravenously administered lipid, protein hydrolysate and glucose in small premature infants. Pediatrics, 56: 8 (1975).

7. Dale, G., Panter-Brick, M., Wagget, J., and Young, G.: Plasma amino acid changes in the post-surgical newborn during intravenous nutrition with a synthetic amino acid solution. J. Pediatr. Surg., 11: 17 (1976).

8. Dixon, W. J., and Massey, F. J.: Introduction to Statistical Analysis. Ed. 3, pp. 150-192 (McGraw-Hill Book Co., Inc., New York, 1969).

9. Energy and Protein Requirements. Wld Hith Org, Tech. Rep. Ser. 522 (1973).

10. Fomon, S. J., and Ziegler, E. E.: Protein intake of premature infants: interpretation of data. J. Pediatr., 90: 504 (1977).

11. Franklin, F. A., Watkins, J. B., Heafitz, L., Clowes, A. M., and Breslow, L. A.: Serum lipids during total parenteral nutrition with Intralipid. Pediatr. Res., 10: 354 (1976).

12. Garza, C., Scrimshaw, N. S., and Young, V. R.: Human protein requirements: the effect of variations in energy intake within the maintenance range. Am. J. Clin. Nutr., 29: 280 (1976).

13. Gaull, G. E., Rassin, D. K., and Raiha, N. C. R.: Protein intake of premature infants: a reply. J. Pediatr., 90: 507 (1977).

14. Golden, M. H. N., and Waterlow, J. C.: Total protein synthesis in elderly people: a comparison of results with ${ }^{15} \mathrm{~N}$-glycine and ${ }^{14} \mathrm{C}$-leucine. Clin. Sci., 53: 277 (1977).

15. Gunn, T., Reaman, G., Outerbridge, E. W., and Colle, E.: Peripheral total parenteral nutrition for premature infants with respiratory distress syndrome: a controlled study. J. Pediatr., 92: 608 (1978).

16. Heird, W. C., Driscoll, J. M., Schullinger, J. N., Grebin, B., and Winters, R. W.: Intravenous alimentation in pediatric patients. J. Pediatr., 80: 351 (1972).

17. Jeejeebhoy, K. N.: Total parenteral nutrition. Ann. Royal Coll. Physicians Surg. Can., 9: 287 (1976).

18. Lindlad, B. S., Settergren, G., Feychting, H. and Persson, B.: Total parenteral nutrition in infants. Acta Paediatr. Scand., 66: 409 (1977).

19. Long, C. L., Zikria, B. A., Kinney, J. M., and Geiger, J. W.: Comparison of fibrin hydrolysates and amino acid solutions in parenteral nutrition. Am. J. Clin. Nutr., 27: 163 (1974).

20. Munro, H. N., and Fleck, A.: Analysis of tissues and body fluids for nitrogenous constituents. In: H. N. Munro: Mammalian Protein Metabolism. Vol. 3, Chap. 30, pp. 424-525 (Academic Press, Inc., New York, 1969).

21. Parsons, H. G., and Pencharz, P. B.: Diurnal variation in various ${ }^{15} \mathrm{~N}$ urea concentration and isotope recycling in children. Fed. Proc. (Abstract 4797), 39: 1180 (1980).

22. Pencharz, P. G. and Jeejeebhoy, K. N.: Regulation of whole body protein synthesis. Lancet, 1 : 1087 (1979).

23. Pencharz, P. B., Masson, M., Desgranges, F., and Papageorgiou, A.: Total body protein turnover in human premature neonates: effects of birth weight, intrauterine nutritional status and diet. Clin. Sci. (in press, 1981).

24. Pencharz, P. B., Steffee, W., Cochran, W., Scrimshaw, N. S., Rand, W. M., and Young, V. R.: Protein metabolism in human neonates. Clin. Sci., 52: 485 (1977).

25. Picou, D., and Taylor-Roberts, T.: The measurement of total protein synthesis and catabolism and nitrogen turnover in infants in different nutritional states and receiving different amounts of dietary protein. Clin. Sci., 36: 283 (1969).

26. Pohlandt, F.: Plasma amino acid concentrations in newborn infants breast-fed $a d$ libitum. J. Pediatr., 92: 614 (1978).

27. Raiha, N. C. R., Heinonen, K., Rassin, D. K., and Gaull, G. E.: Milk protein 
quantity and quality in low birth weight infants. I. Metabolic responses and effects on growth. Pediatrics, 57: 659 (1976)

28. Scriver. C. R., and Rosenberg, L. E.: Amino acid metabolism and its disorders. pp. 39-50 (W. B. Saunders Ltd., Philadelphia, 1973).

29. Sim. A. J. W., Wolfe, B. M., Young V. R., Clarke, D., and Moore, F. D.: Glucose promotes whole-body protein synthesis from infused amino acids in fasting man. Lancet, $1: 68$ (1979).

30. Steffee. W. P., Goldsmith, R. S., Pencharz. P. B., Scrimshaw, N. S., and Young V. R: Dietary protein intake and dynamic aspects of whole body nitrogen metabolism in adult humans. Metabolism, 25: 281 (1976).

31. Sunshine, P. (ed.): Gastrointestinal development and neonatal nutrition. Report of the 72nd Ross Conference on Research. (Ross Laboratories, Columbus. Ohio, 1977)

32. Widdowson, E. M.: Growth and composition of the fetus and newborn. In: N. S. Assali: Biology of gestation, Vol. 2, pp. 1-49 (Academic Press, Inc., New York. 1968).

33. Young. V.R., and Munro, H. N.: $\mathrm{N}^{\gamma}$-Methylhistidine (3-methyl-histidine and muscle protein turnover: an overview. Fed. Proc., 37: 2291 (1978).

34. Vamin and Intralipid are marketed in Canada by Pharmacia, Dorval, Quebec.

35. This study was presented in part at the Society for Paediatric Research Annual
Meeting in San Antonio, Texas, U. S. A., April 30, 1980

36. Dr. B. Duffy was supported by a fellowship from the McGill University-Montreal Children's Hospital Research Institute.

37. The present address of Dr. Duffy is: Prince of Wales Children's Hospital, High Street, Randwick 2031, N.S.W., Australia.

38. The present address of Dr. Gunn is: Auckland Hospital Board, St. Helens Hospital, Linwood Avenue, Mt. Albert, Auckland 3, New Zealand.

39. The authors would like to thank Dr. E. Outerbridge, Director of Neonatology at the Montreal Children's Hospital, for his support and encouragement; the nurses of the Neonatal Care Unit for their invaluable assistance in the conduct of the balance and turnover studies; and Dr. G. Harvey Anderson, Department of Nutrition and Food Science, University of Toronto, for assistance in carrying out the urinary 3-methyl histidine and plasma amino acid analyses.

40. Requests for reprints should be addressed to: Dr. P. B. Pencharz, The Hospital for Sick Children, 555 University Avenue, Toronto, Ontario, Canada M5G IX8.

41. This research was supported in part by the Medical Research Council of Canada grant MA-5466, and a grant from Pharmacia, Dorval, Quebec, Canada.

42. Received for publication July $22,1980$.

43. Accepted for publication October 20, 1980. 